he and his wife, Ellen, were named National Parents of the Year by the Association of the Severely Handicapped. Don's activism-always ardent and constructive-extended into several areas of social concernsports, conservation, water pollution, Democratic party politics, among others. He taught himself to become an expert wind-surfer, and loved many water sports, both as an observer and a participant.

Yet Don will not be remembered most for his social activism or his many academic accomplishments. It will be for his status as a man, a most humane and loving person.

Certainly not least, Don Hadwiger's death was the cause of much anguish and sadness to his colleagues in the Department of Political Science, and those of us elsewhere. He was a splendid colleague, mentor and friend; to say that he is already greatly missed would be a grievous understatement. His passing brought tears; his life brought us joy.

Ross Talbot

Ardith Maney

Iowa State University

William Browne

Central Michigan University

\section{William R. Kintner}

William R. Kintner, 81, a soldier, scholar, diplomat, author, and professor emeritus of political science at the University of Pennsylvania, died on February 1 after a long bout with cancer.

Born in Lock Haven, PA, Kintner graduated from West Point in 1940 with a B.A. and a commission as second lieutenant. He continued his education at Georgetown, where he took an M.A. and a Ph.D.; his doctoral dissertation, The Front is Everywhere, a study of the Soviet Communist Party, was published in 1950.

Kintner retired from the Army in 1961 at the rank of colonel. At the time, he held various posts within the Office of the Chief of Research and Development and the strategy analysis coordination group for the Army's Chief of Staff. He also had earned a Bronze Star and a Legion of Merit, both with oak leaf clusters.

When he retired, Kintner was appointed professor of political science at the University of Pennsylvania. During his tenure, he was active in the Foreign Policy Research Institute (FPRI), where he served as deputy director from 1961, and became director in 1969 . In 1970 Kintner was to oversee the separation of the Institute from the Univesity as Penn implemented a policy prohibiting classfied research, which was applicable to some FPRI research on arms control.

In 1973, Kintner left his post as director to become then-President Ford's ambassador to Thailand. He had the task of securing Thai support for a war that the United States was leaving. He returned to Philadelphia in 1975 to assume the position of president of FPRI. A highlight of his achievements was orchestrating a joint project with the Soviet Institute for the Study of the United States and Canada that permitted annual exchanges of top nongovernmental scholars and analysis despite the Cold War. Retiring from the Institute in 1985, he served on the board of directors of the United States Institute for Peace.

Kintner authored many books, including Forging a New Sword with Joseph Coffey and Raymond Albright; A Forward Strategy for America with Robert Strauss-Hupé and Stephan Possony; and Soviet Global Strategy. He also published in Esquire, National Review, Reader's Digest and the New Leader. His last book, The Role of Ancient Israel, subtitled $A$ Swedenborglan Perspective, was published in 1996.

Reproduced with permission from $\mathrm{Al}$ manc, a University of Pennsylvania publication.

\section{Nicholas A. Masters}

Nicholas A. Masters, 67, a former political science professor and Capitol Hill aide who was legislative affairs director of the Belew Law Firm in Washington, DC, died of a heart attack November 3 in Alexandria, VA.

Masters worked for the House Budget Committee from 1974 to 1993, serving as majority staff director and special assistant to the chairman of the committee. Earlier, he worked as an aide to Sen. Philip Hart (D-Mich.), as a legislative con- sultant to the Joint Committee on the Organization of Congress and as staff director of the Joint Committee on Congressional Operations. He became a legislative consultant to the law firm of Winston and Strom in 1993, then joined Belew.

Between 1955 and 1974, he was a professor of political science at Pennsylvania State and Southern Illinois universities and also taught at Wayne State and Washington universities.

Masters was a native of Carbondale, Ill. He served in the Navy in Guam during World War II. He was a graduate of Southern Illinois University, where he also received a master's degree in political science. $\mathrm{He}$ received a doctorate in political science at the University of Wiscon$\sin$.

He was a research consultant to former Harvard University president James B. Conant on a project on education in the United States; coauthor of a book, "State Politics and Public Schools"; and author of "The Greater Powers of the Presidency." He also wrote for scholarly journals.

Adapted from The Washington Post

\section{John H. Millett}

John H. Millett, emeritus professor of political science at Wichita State University, died January 26th at age 77 in Sarosota, Florida, following complications from heartbypass surgery. A native of Wheaton, Illinois, John earned his Phi Beta Kappa key at Beloit College where he received his B.A. in 1940. He took a M.A. in public administration from the University of Cincinnati in 1942. Following service as an army captain in Korea during World War II, John enrolled at the University of Illinois where he received the Ph.D. in 1950.

John's first full-time teaching position was at the University of Rochester (1948-1957) where he taught, among other courses, upper-division classes in public administration. Why would John Millett teach public administration? He did because Rochester hired him for that. As John would remind colleagues with grim humor, his dissertation, after all, was 
entitled "Public Employee Unionism in Downstate Illinois Municipalities." His training in public administration notwithstanding, John discovered his true interests at Rochester-British and comparative politics, "the Behavioral Revolution" (words and emphasis his), group theory, and Arthur Bentley, probably in that order.

To further his interests in British politics and group theory, John did research in England on the British Legion during the 1954-55 academic year on a fellowship from the Fund for the Advancement of Education. (John had many stories to tell of his voyage aboard the Queen Mary) The fellowship led to publication in the Western Political Quarterly of "The Role of an Interest Group Leader in the House of Commons," the work for which John is best known. The article was reprinted in Heinz Eulau and John Wahlke's Legislative Behavior and was also cited in many bibliographies dealing with British politics or group theory.

John came to what was the University of Wichita in September 1957 and remained until his retirement in May 1984, save for the 1964-65 academic year when he filled in for John Kautsky, who was on leave from Washington University. Vice president of the Midwest Political Science Association during 1974-75, John was a professional political scientist in every sense, but he was also much more. He was a man who loved learning. He told the local Pi Sigma Alpha members at his retirement of his visit to the University of Virginia near the end of World War II. It was his first visit to a campus since the war began. So overjoyed to be at a center of learning once again, John expressed this joy by rolling down a hill.

As a man of learning, John endeavored to pass on his erudition to his students. At Wichita State John was director of the Honors Program from 1968 through the spring of 1971. Encouraging his students to pursue a broad liberal education, John admonished them not to concentrate all of their academic effort within the narrow confines of a major. One of John's students, Wes McCarty, religiously followed John's advice and sought to become a wellrounded student. When Wes died untimely of leukemia, his parents, remembering John's work with Wes, established an endowed departmental scholarship in honor of Wes which specified that the recipients were to pursue a broad liberal education. In reality the scholarship was as much a memorial to John Millett as to Wes McCarty. The creation of that scholarship led to the establishment of several other endowed scholarships for undergraduates. John was also known for his role as adviser to Pi Sigma Alpha. The induction of members was no casual matter for John. Instead, he arranged an annual induction banquet which he saw as an august and solemn rite.

John retired from Wichita State in May of 1984. The department planned a grand gala to honor him. Political scientists and former students from around the country were planning to attend John's retirement celebration. But John's doctor advised him that he needed immediate by-pass surgery if he were to live. So the departmental chair called invited guests around the country to tell them that the celebration has been cancelled. John's retirement party was rescheduled for May of 1985, but it was anti-climatic. For many years John believed that his doctors had conspired against him to deny him his retirement party.

Despite his disappointment over the cancelled retirement fete and his failing health in his last years, John had a good life in retirement. He and his wife Marie, whom he had married on June 1, 1975, moved to Sarasota in 1986. Active in Grapevine International Folk Dancers and other dance groups since the time of his marriage, John had a longtime dream come true when he and Marie took a folk dance tour of Greece during his retirement. Until just a few months before his death, John and Marie folk danced as often as four evenings a week.

Aside from folk dancing, John followed the stock market closely, just as his father, an Episcopal minister, had done. When his congregation cut the Rev. Mr. Millett's salary during the depression, the minister took to playing the stock market to make up the difference. The Rev. Mr. Millett made such handsome profits that a nicely sum of John's retirement income came from investments John inherited from his father. For years John touted the shares of Hesston Corp., a Kansas manufacturer of farm machinery. Hesston did not prosper, and John lost money. Yet he maintained his interest in the market and endured much goodnatured ribbing about the fate of Hesston.

A strong supporter of the Unitarian Universalist fellowship in Wichita-believe in one God at most," John would proclaim-John was an active Unitarian in Sarasota as well. But this erudite man with a liberal education also found time for other pursuits. He took piano lessons. A friend who visited him at the "Millett Hilton" recalls him "proudly playing Bach, Chopin, and Haydn pieces in recitals with students of all ages." He became an expert on the birds of Florida and attended the Sarasota Music Festival every June. He even found time to volunteer as a paraprofessional at a pre-school and to serve on its Board of Directors. Those wishing to honor the memory of John may make a contribution to that pre-school, Helen R. Payne Day Nursery, P.O. Box 3365, Sarasota, Fla. 34230, or to the Unitarian Universalist Church, 3975 Fruitville Road, Sarasota, FL 34232.

Kenneth N. Ciboski

David N. Farnsworth (emeritus)

Melvin A. Kahn

James W. McKenney

James F. Sheffield, Jr. John E. Stanga

Wichita State University

\section{Donald E. Stokes}

Donald E. Stokes died of acute leukemia on January 26, 1997, at the University of Pennsylvania Medical Center. He was 69. He was the Class of 1943 University Professor of Politics and Public Affairs at Princeton University, where he had been a member of the faculty for 23 years and Dean of the Woodrow Wilson School of Public and International Affairs from 1974 to 1992.

Born April 1, 1927, in Philadelphia, Stokes earned his bachelor's degree from Princeton in 1951 and his doc- 